Current Status of Deep

Geological Repository

Development

R. J.Budnitz

September 2, 2005

International Seminar on Planetary Emergencies

Erice, Italy

August 20, 2005 through August 23, 2005 
This document was prepared as an account of work sponsored by an agency of the United States Government. Neither the United States Government nor the University of California nor any of their employees, makes any warranty, express or implied, or assumes any legal liability or responsibility for the accuracy, completeness, or usefulness of any information, apparatus, product, or process disclosed, or represents that its use would not infringe privately owned rights. Reference herein to any specific commercial product, process, or service by trade name, trademark, manufacturer, or otherwise, does not necessarily constitute or imply its endorsement, recommendation, or favoring by the United States Government or the University of California. The views and opinions of authors expressed herein do not necessarily state or reflect those of the United States Government or the University of California, and shall not be used for advertising or product endorsement purposes. 


\title{
CURRENT STATUS OF DEEP GEOLOGICAL REPOSITORY DEVELOPMENT
}

\author{
Robert J. Budnitz \\ Lawrence Livermore National Laboratory \\ 7000 East Avenue, Mail Stop L-632 \\ Livermore CA 94551 USA \\ e-mail: budnitz1@ @LNL.gov
}

[For the "International Seminar on Planetary Emergencies", Erice, Italy, 20-23 August 2005]

This talk provided an overview of the current status of deep-geological-repository development worldwide. Its principal observation is that a broad consensus exists internationally that deep-geological disposal is the only long-term solution for disposition of highly radioactive nuclear waste. Also, it is now clear that the institutional and political aspects are as important as the technical aspects in achieving overall progress.

Different nations have taken different approaches to overall management of their highly radioactive wastes. Some have begun active programs to develop a deep repository for permanent disposal: the most active such programs are in the United States, Sweden, and Finland. Other countries (including France and Russia) are still deciding on whether to proceed quickly to develop such a repository, while still others (including the UK, China, Japan) have affirmatively decided to delay repository development for a long time, typically for a generation of two.

In recent years, a major conclusion has been reached around the world that there is very high confidence that deep repositories can be built, operated, and closed safely and can meet whatever safety requirements are imposed by the regulatory agencies. This confidence, which has emerged in the last few years, is based on extensive work around the world in understanding how repositories behave, including both the engineering aspects and the natural-setting aspects, and how they interact together. The construction of repositories is now understood to be technically feasible, and no major barriers have been identified that would stand in the way of a successful project.

Another major conclusion around the world is that the overall cost of a deep repository is not as high as some had predicted or feared. While the actual cost will not be known in detail until the costs are incurred, the general consensus is that the total life-cycle cost will not exceed a few percent of the value of the electricity generated by the power reactors that have produced the waste.

Of course, the current international situation is that no nation is currently willing to take any radioactive waste from another nation for deep disposal. This means that every nation will ultimately need to develop its own deep repository. This makes no sense, however -- many nations have only a modest amount of waste, or do not have appropriate geological settings for a repository, or both. Ultimately, the need for one or more multi-national or international repositories will emerge, although so far this has not happened. 
Only one nation, Russia, has announced a policy permitting the import of radioactive wastes from other countries, but Russia's policy is not to import the wastes for deep disposal, but for chemical reprocessing.

Various nations have made very different choices as to the schedule for proceeding with a repository. The rationales for each national choice differ significantly. The decision, different from country to country, comes down to balancing various seemingly conflicting values, including (a) whether the technology for deep disposal is judged to be mature enough; (b) whether surface storage during a lengthy delay is judged adequately safe against accidents and adequately secure against terrorists; (c) whether technologies for separating some of the waste constituents for re-use or re-cycle into reactors, or technologies for transmuting some waste constituents, are sufficiently promising to merit delaying until those technologies are more mature; (d) issues of the cost of disposal and who should bear that cost; (e) issues related to disposal of wastes from nuclearweapons programs, as distinct from wastes from reactor operations; and (f) issues about the linkage between disposal and the future of nuclear power.

Finally, the decision to proceed with a repository often is governed by whether the government has the political will or ability to proceed, taking account of public opinion. In some countries, significant opposition to proceeding with repository development has led to a decision to defer for decades or more, while in other countries the political process of developing choices is not yet under way. In several countries, there have been important lessons-learned about how to involve the public early-on in wastedisposition decisions rather than only later, and about how to explain the rationale for whatever policies the government seeks to implement.

This work was performed under the auspices of the U.S. Department of Energy by University of California, Lawrence Livermore National Laboratory under Contract W-7405-Eng-48. 